\begin{tabular}{|c|c|c|}
\hline $\begin{array}{l}\text { UAD } \\
\text { Universitas } \\
\text { Ahmad Dahlan }\end{array}$ & $\begin{array}{c}\text { MIMESIS } \\
\text { VoL. 2. No. 2, Juli } 2021\end{array}$ & \\
\hline
\end{tabular}

\title{
CORPUS LINGUISTICS PROJECT: SEEKING THE USE OF DEMONSTRATIVE IN SONGS WRITTEN BY EMINEM
}

\author{
Ana Nisa Ussolichah \\ Email : nisaa7636@gmail.com \\ Universitas Tidar, Magelang \\ Arindi Indra \\ arindiindra2@gmail.com \\ Universitas Tidar, Magelang \\ Lilia Indriani \\ indriani@untidar.ac.id \\ Universitas Tidar, Magelang
}

Article history

Received 08 June 2021

Revised 18 July 2021

Accepted 22 July 2021

Keywords

Demonstrative, Seeking

Eminem Songs, Corpus,

Linguistics Project

The object of this study is to identify the kinds of demonstrative that are used in the songs written by Eminem. In English, there is the word this, that, these, and those. Demonstratives are used to designate the place for an object, person, or thing and to indicate pronouns that have already been mentioned. The song contains lyrics and music. Songs can be used as an accessible learning medium in learning a foreign language. In improving understanding of English about demonstrative, this research belongs to qualitative research to find out the dominant types of demonstrative used in the songs by Eminem. Researchers use the observation method to collect data, while the data collection technique is listening and analyzing the songs. The data obtained came from the songs contained in the album written by Eminem from 2009 to 2014. In this study, researchers looked for the most widely used demonstrative words in Eminem's song lyrics. There were 59 songs in the analysis and consisted of 5 albums. The use of demonstratives in the song is very much, especially the demonstrative "That." That is used to replace singular and uncountable nouns that are far away.
\end{abstract}

This is an open access article under the CC-BY-SA license.

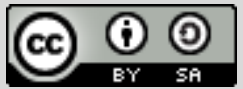

\section{INTRODUCTION}

The language is a system of articulated signifying sound symbols that are arbitrary and conventional, used to communicate by a group of people for feelings and thoughts. (Wibowo, 2001: 3). Language is the most crucial system in human life. In everyday life, everyone will communicate with others with language. Speaking is one of the essential aspects of human life for survival. People will not be able to live alone; they will need other people and need to communicate with others because, in essence, humans are born as social creatures whose lives depend on other people. Language is the only system or tool used by humans to communicate with others.

Socially collectively, language is a means of interacting with each other (Pringgawidagda, 2002: 4). According to Ferdinand De Saussure, language is the most prominent distinguishing feature because, with language, each social group feels like a different unit from other groups. Meanwhile, according to cognitive psychologists, language is a communication system in which thoughts are transmitted (transmitted) by voice (as in 


UADESIS
Universitas
Ahmad Dahlan

written words or physical cues). With language people will be easier to communicate with others. Apart from learning the mother tongue, and the national language (the country's official language), we must also to master foreign languages. Language is important in learning because these activities focus on how to move humans/learners to carry out learning activities. Language becomes a delivery medium so that learning reaches a certain point as a predetermined competency. As speakers of a language in communicating, some elements in learning place humans as the same elements, while other elements are complementary to be able to express language in learning communication (Bakhtiar, 2014: 93). Human knowledge can develop due to two factors. First, humans have a language capable of communicating information and thinking that is the background of the information. Second, humans can though according to a particular line of thinking framework-development of language and broader human knowledge. In the world of education today, there is foreign language learning. A foreign language is a language that is not the native language of a particular country. Foreign languages are used as a second choice in subjects and not used for daily communication. Foreign language studies began when the Romans learned Greek as their second language before the 19th century. Foreign languages begin to be studied by Europeans, thought of methods for teaching a second or foreign language.

Today English is one of the most studied foreign languages. Chomsky (1965) considers language skills to be the mastery of language rules (competence) and how to use them (performance). In line with Chomsky's opinion, in learning, people have to understand the use of words in English, one of which is demonstrative. Demonstrative consists of the words this, that, these, and those. Demonstratives are used to designate an object, person, or thing and to indicate pronouns that have already been mentioned.

Songs are a medium using in English learning activities. Songs with various genres and sung using a good voice can make it easier to understand language, intonation, and pronunciation. The song consists of lyrics and music. Moeliono (2007: 628) explained that song lyrics are literary works in poetry that contain an outpouring of the heart as the composition of a song. To use a lyric, a poet must be good at processing words. Based on the explanation, this research focuses on finding the word demonstrative in Eminem's song. The songs that will be analyzed consist of songs in Eminem's 5 albums from 2009 to 2014.

Several previous researchers have examined the same topic related to this study. Firstly, it is carried out by Roy Randy Y. Briones, with his research entitled A Demonstrative Analysis of News Articles Using Fairclough's Critical Discourse Analysis Framework. This research is about demonstrating Norman Fairclough's Critical Discourse Analysis (CDA) framework by conducting an internal and external level analysis of two online news articles that report submission of their findings to the Moro Islamic Liberation Front (MILF) regarding the "Mamasapano Incident" that occurred in the Philippines in 2015.

Ade Irma Suryani writes the second research with her research entitled A Contrastive Study of Demonstrative Pronoun In English and Japanese. This researcher studies the research report, which consists of discussing the various kinds, functions, and positions of demonstrative pronouns in English and Japanese.

As early-stage EFL students, they must understand what is demonstrative. Demonstratives (truncated dem) are words, such as this and that, utilized to show which substances are being referred to and to recognize those substances from others. They are typically deictic; their meaning depends on a specific outline of reference and cannot be caught without setting. Demonstratives are frequently utilized in spatial deixis (where the speaker or some of the time the listener are to supply setting), but too in intra-discourse reference (counting theoretical concepts) or anaphora, where the meaning is subordinate on 


UAD
Universitas
Ahmad Dahlan

something other than the relative physical area of the speaker, for illustration whether something is right now being said or was said prior. One thing that students must know in learning English is the use of demonstrative. As EFL students, they must become familiar with what a demonstrative is, create it and use it. Understanding demonstrative is essential for EFL students because demonstrative is always there, even in simple English.

In this research, the writer will seek demonstrative use, especially demonstrative with singular nouns \& uncountable nouns, and demonstrative with plural countable nouns.

\begin{tabular}{lcc}
\hline & $\begin{array}{c}\text { Away from the } \\
\text { speaker }\end{array}$ & \multicolumn{1}{c}{ Close to the speaker } \\
\hline $\begin{array}{l}\text { Demonstrative with singular } \\
\text { nouns } \\
\text { \& uncountable nouns }\end{array}$ & That & This \\
\hline $\begin{array}{l}\text { Demonstrative with } \\
\text { plural countable nouns }\end{array}$ & Those & These \\
\hline
\end{tabular}

Example of using the words this, that, these, and those:

- Is this Emil's house?

- Is that John's car over there?

- These flowers are mine.

- Those grapes are yours.

From the above statement, the author is interested in using demonstrative in songs written by Eminem, especially demonstrative with singular nouns \& uncountable nouns, and demonstrative with plural countable nouns. This research data is a demonstrative word found from the songs contained in the album written by Eminem from 2009 to 2014. The observation method used by researchers to collect data is the data collection technique with listening and analyzing the songs. The data obtained came from the songs contained in the album written by Eminem from 2009 to 2014.

\section{METHOD}

According to Sugiyono (2011), the research method is a scientific way to obtain data with specific purposes and uses. In this research, the method used is the descriptive qualitative method. According to Winartha (2006: 155), the descriptive analysis method analyzes, describes, and summarizes various conditions, situations from multiple data collected in interviews or observations regarding the problems to be studied. Meanwhile, according to Sugiyono (2008: 4), the analysis method is a method based on the postpositivism philosophy, used to examine natural object conditions, where the researcher is the key instrument.

Qualitative research results focus on meaning rather than generalizations. This research emphasizes the meaning of the results. Here the role of the searcher is as the primary data collector. Researchers use the observation method to collect data, while the data collection technique is listening and analyzing the songs. The research data came from the analysis of songs from Eminem. The songs that will be analyzed are the songs contained in the 5 Eminem albums from 2009 to 2014. The data will contain the number of expressive words that are the most widely used in each song. 


\section{RESULTS AND DISCUSSION}

In this research, researchers collected data from listening to songs then analyzing the lyrics. The data obtained will show the number of demonstrative pronouns in the song. The data also shows the most widely used demonstrative pronouns. The total data obtained is 1,105. The data from the analysis of Eminem's song lyrics are as follows:

Table 1: Number of songs in Relapse: Refill (2009) album

\begin{tabular}{|c|c|c|c|c|c|c|}
\hline \multirow[t]{2}{*}{ No } & \multirow[t]{2}{*}{ Song Title } & \multicolumn{4}{|c|}{ Analysis Word } & \multirow[t]{2}{*}{ Total } \\
\hline & & This & That & These & Those & \\
\hline 1 & Forever & 18 & 7 & 3 & - & 28 \\
\hline 2 & Hell Breaks Loose & 13 & 15 & - & - & 28 \\
\hline 3 & Bufallo Bill & 1 & 3 & & 21 & 25 \\
\hline 4 & Elevator & 6 & 22 & 1 & - & 29 \\
\hline 5 & Taking My Ball & - & 4 & - & 1 & 5 \\
\hline 6 & Music Box & 2 & 5 & - & - & 7 \\
\hline 7 & $\begin{array}{l}\text { Drop the Bomb } \\
\text { On'em }\end{array}$ & 3 & 5 & - & - & 8 \\
\hline & Total & 43 & 61 & 4 & 22 & 130 \\
\hline
\end{tabular}

From the table above, it can be seen that the total of the total demonstrative pronouns analyzed is 130. "That" is the most widely used demonstrative pronoun in the song lyrics on the Refill album, with a total of 61. "That" refers to nouns that are further away in time or space. Then the second most are "This" with a total of 43. "This" refers to nouns that are nearby in time or space. In third place, there are "Those" with 22 and finally "These" with a total of 4 .

Table 2: Number of songs in Recovery (2010) album

\begin{tabular}{|c|c|c|c|c|c|c|}
\hline \multirow[t]{2}{*}{ No } & \multirow[t]{2}{*}{ Song Title } & \multicolumn{4}{|c|}{ Analysis Word } & \multirow[t]{2}{*}{ Total } \\
\hline & & This & That & These & Those & \\
\hline 1 & Cold Wind Blows & 9 & 11 & 1 & - & 21 \\
\hline 2 & Talkin & 6 & 8 & 2 & 1 & 17 \\
\hline 3 & On Fire & 10 & 6 & 1 & 2 & 19 \\
\hline 4 & $\begin{array}{l}\text { Won't Back } \\
\text { Down }\end{array}$ & 2 & 12 & 2 & - & 14 \\
\hline 5 & W.T.P & 5 & 10 & - & - & 20 \\
\hline 6 & $\begin{array}{l}\text { Going Through } \\
\text { Changes }\end{array}$ & 7 & 6 & 1 & - & 14 \\
\hline 7 & Not Afraid & 11 & 9 & 4 & 1 & 30 \\
\hline 8 & Seduction & 3 & 12 & 1 & - & 16 \\
\hline 9 & Space Bound & 6 & 7 & 1 & - & 14 \\
\hline 10 & No Love & 3 & 11 & 6 & - & 20 \\
\hline 11 & Cinderella Man & 5 & 3 & - & - & 8 \\
\hline 12 & 25 to Life & 11 & 6 & - & - & 17 \\
\hline 13 & So Bad & 3 & 11 & 1 & - & 15 \\
\hline 14 & Almost Famous & 6 & 4 & 13 & - & 23 \\
\hline 15 & Love The Way & 2 & 16 & - & - & 18 \\
\hline
\end{tabular}




\begin{tabular}{|c|c|c|c|c|c|c|}
\hline \multicolumn{3}{|c|}{ You Lie } & & & & \\
\hline 16 & $\begin{array}{c}\text { You're Never } \\
\text { Ever }\end{array}$ & 13 & 10 & 3 & - & 26 \\
\hline 17 & Untitled & 3 & 8 & - & - & 11 \\
\hline 18 & Ridaz & 9 & 9 & - & - & 18 \\
\hline 19 & Session One & 9 & 6 & - & - & 15 \\
\hline & Total & 151 & 165 & 36 & 4 & 336 \\
\hline
\end{tabular}

From the table above, the total number of demonstrative pronouns is 336 . Of the 19 songs analyzed, "That" is the most widely used demonstrative pronoun in this album with a total of 165 songs, the same as in the Refill album. "This" is the second most demonstrative pronoun with a total of 151 followed by "These" in third place with a total of 36, and "Those" coming in last with a total of 4.

Table 3: Number of songs in Straight From the Vault (2011) album

\begin{tabular}{|c|c|c|c|c|c|c|}
\hline \multirow[t]{2}{*}{ No } & \multirow[t]{2}{*}{ Song Title } & \multicolumn{4}{|c|}{ Analysis Word } & \multirow[t]{2}{*}{ Total } \\
\hline & & This & That & These & Those & \\
\hline 1 & $\begin{array}{c}\text { The People's } \\
\text { Champ }\end{array}$ & 3 & 3 & - & - & 6 \\
\hline 2 & Get Money & 3 & 8 & - & - & 11 \\
\hline 3 & Emulate & 4 & 6 & 2 & - & 12 \\
\hline 4 & Things Get Worse & 11 & 4 & - & - & 15 \\
\hline 5 & $\begin{array}{c}\text { Ballin' } \\
\text { Uncontrollably }\end{array}$ & 2 & 7 & 1 & - & 10 \\
\hline 6 & $\begin{array}{c}\text { My Dad's Gone } \\
\text { Crazy }\end{array}$ & 4 & 10 & 1 & - & 15 \\
\hline 7 & Wee Wee & - & 8 & - & - & 8 \\
\hline 8 & G.O.A.T & 4 & 24 & 3 & 6 & 37 \\
\hline 9 & The Apple & 7 & 3 & - & 1 & 11 \\
\hline 10 & It's Been Real & 3 & 1 & - & - & 4 \\
\hline 11 & Fly Away & 4 & 2 & 3 & - & 9 \\
\hline & Total & 45 & 76 & 10 & 7 & 138 \\
\hline
\end{tabular}

In the album Straight From the Fault, the total of demonstrative pronouns is 138 . From the table above, it can be seen that "That" is still the most demonstrative pronoun as in the previous album, with a total of 76 in the song. "This" is also still the second most demonstrative with a total of 45 . Followed by "These" in third place with a total of 10 and in fourth place was "Those" with 7.

Table 4: Number of songs in The Marshall Mathers LP 2 (2013) album

\begin{tabular}{|c|c|c|c|c|c|c|}
\hline \multirow[t]{2}{*}{ No } & \multirow[t]{2}{*}{ Song Title } & \multicolumn{4}{|c|}{ Analysis Word } & \multirow[t]{2}{*}{ Total } \\
\hline & & This & That & These & Those & \\
\hline 1 & Baby & 7 & 16 & - & - & 23 \\
\hline 2 & Bad Guy & 17 & 23 & - & 1 & 41 \\
\hline 3 & Beautiful Pain & 5 & 8 & - & - & 13 \\
\hline 4 & Berzerk & 9 & 10 & 1 & - & 20 \\
\hline 5 & Brainless & 14 & 7 & 2 & 1 & 24 \\
\hline
\end{tabular}




UADESIS
Universitas
Ahmad Dahlan

\begin{tabular}{ccccccc}
\hline $\mathbf{6}$ & Desperation & 16 & 13 & - & - & 29 \\
\hline $\mathbf{7}$ & Don't Front & 2 & 13 & 1 & 3 & 19 \\
\hline $\mathbf{8}$ & Evil Twin & 8 & 15 & 3 & - & 26 \\
\hline $\mathbf{9}$ & Groundhog Day & 11 & 6 & 1 & - & 18 \\
\hline $\mathbf{1 0}$ & Headlights & 12 & 11 & - & - & 23 \\
\hline & Total & 101 & 122 & 8 & 5 & 236 \\
\hline
\end{tabular}

In the Marshall Mathers LP 2, the researcher analyzed ten songs and got 236 demonstrative pronoun words in all the songs. "That" is the most demonstrative pronoun used in the entire song, especially in the song Bad Guy with 23 words. The total number of demonstrative pronouns "That" is 122 . The second highest order of demonstrative pronouns is "This," with 101 and the most number found in the song Bad Guy with 17 words. The third highest place is "These" with a total of 8 and finally "Those" with five words.

Table 5: Number of songs in Shady XV (2014) album

\begin{tabular}{|c|c|c|c|c|c|c|}
\hline \multirow[t]{2}{*}{ No } & \multirow[t]{2}{*}{ Song Title } & \multicolumn{4}{|c|}{ Analysis Word } & \multirow[t]{2}{*}{ Total } \\
\hline & & This & That & These & Those & \\
\hline 1 & $\begin{array}{l}\text { Detroit Vs } \\
\text { Everybody }\end{array}$ & 13 & 26 & 4 & - & 43 \\
\hline 2 & Die Alone & 5 & 5 & 3 & - & 13 \\
\hline 3 & Down & 10 & 16 & 4 & - & 30 \\
\hline 4 & Fine Line & 11 & 5 & 2 & 1 & 19 \\
\hline 5 & Guts Over Fear & 11 & 13 & - & - & 24 \\
\hline 6 & Lose Yourself & 10 & 3 & - & - & 13 \\
\hline 7 & Psycpath Killer & 5 & 7 & 3 & - & 15 \\
\hline 8 & Right For Me & 4 & 16 & - & - & 20 \\
\hline 9 & Shady & 7 & 17 & 2 & - & 26 \\
\hline 10 & Twisted & 7 & 10 & - & - & 17 \\
\hline 11 & Vegas & 13 & 14 & 2 & 1 & 30 \\
\hline 12 & Y'all Ready Know & 4 & 10 & 1 & - & 15 \\
\hline & Total & 100 & 142 & 21 & 2 & 265 \\
\hline
\end{tabular}

In this Shady XV album, the total demonstrative pronoun is 265 , with "That" being the most used demonstrative. The total "That" in the entire song on this album is 142 words. "This" is the second most demonstrative with a total of 100 words. "These" with a total of 21 is the third most. "Those" came in the last place with a total of 2 words.

\section{CONCLUSION}

Demonstratives are divided into the words this, that, these, and those. In this study, researchers looked for the most widely used demonstrative words in Eminem's song lyrics. There were 59 songs in the analysis and consisted of 5 albums. The use of demonstratives in the song is very much, especially the demonstrative "That". That is used to replace singular and uncountable nouns that are far away. 


UADESIS
Universitas
Ahmad Dahlan

In the lyrics of Eminem's song, rap, demonstratives are used to replace nouns. The use of demonstratives makes the lyrics more colorful in describing the song to be not monotonous. Through this research, the researcher knows that demonstrative song lyrics play significant role. It is because almost all kinds of words from demonstrative pronouns are in every song. In addition, knowing the function and use of demonstratives is very important in using good grammar in communication.

\section{REFERENCES}

Ayu, K. D. (2019). Peranan bahasa dalam pengembangan ilmu pengetahuan. ResearchGate. doi:http://dx.doi.org/10.31227/osf.io/6w4xa

Briones, R. R. (2017). A demonstrative analysis of news articles using fairclough's critical discourse analysis framework. Beyond Words. doi:https://dx.doi.org/10.33508/bw.v5i1.1117

Catasso, N. (2011). The grammaticalization of demonstratives: a comparative analysis. Journal of Universal Language. doi:http://dx.doi.org/10.22425/jul.2011.12.1.7

D, W. (2017). Metode penelitian. 63-71. Retrieved from $\mathrm{http}: / /$ repository.radenintan.ac.id/2411/5/BAB_III_bu_dian.pdf

Dewi, K. S. (2020). Pentingnya menguasai bahasa inggris dalam era globalisasi masa kini. Retrieved from kompasiana: https://www.kompasiana.com/karinasofia13/5e4d18f0d541df2b1627e552/pentingnyamenguasai-bahasa-inggris-dalam-era-globalisasi-masa-kini?page $=$ all

FARLEX. (2020). Demonstrative pronouns. Retrieved from THE FREE DICTIONARY BY FARLEX: https://www.thefreedictionary.com/Demonstrative-Pronouns.htm

Ginger. (2021). Demonstrative pronouns. Retrieved from GINGER: https://www.gingersoftware.com/content/grammar-rules/demonstrative-pronouns/

HC Editor Indonesia. (2015). Apa itu efl (english as foreign language). Retrieved from hotcoursesINDONESIA: https://www.hotcourses.co.id/study-abroad-info/universityapplications/apa-itu-efl-english-as-a-foreign-language/

Hertzberg, K. (2019). Here's how to write an introduction (with examples and tips).

Retrieved from grammarly blog: https://www.grammarly.com/blog/how-to-write-anintroduction/

Jennifer Betts. (2020). Effective research abstract examples. Retrieved from YOUR DICTIONARY: https://examples.yourdictionary.com/effective-research-abstractexamples.html

Lailli. (2020). Teks analisis data penelitian kuantitatif. Retrieved from TambahPinter.com: https://tambahpinter.com/teknik-analisis-penelitian-kuantitatif/

Listiani, H. (2015). An analysis of figurative language found on the song lyric by taylor swift's "speak now" album. Retrieved from http://erepository.perpus.iainsalatiga.ac.id/135/1/Heny\%20Listiani_11310090.pdf

Merriam_Webster. (2021). Demonstrative 1 definition of demonstrative by merriam-webster. Retrieved from Merriam-Webster: https://www.merriamwebster.com/dictionary/demonstrative 


\begin{tabular}{|c|c|c|}
\hline $\begin{array}{l}\text { UAD } \\
\text { Universitas } \\
\text { Ahmad Dahlan }\end{array}$ & $\begin{array}{c}\text { MIMESIS } \\
\text { VoL. 2. No. 2, Juli } 2021\end{array}$ & \\
\hline
\end{tabular}

Miller-Wilson, K. (2021). Strong introduction paragraph examples. Retrieved from YOUR DICTIONARY: https://examples.yourdictionary.com/strong-introductionexamples.html

Mujtaba, A. (2016). Manfaat dan pentingnya belajar bahasa inggris di era globalisasi. Retrieved from ENGLISH ONLINE: https://belajarbahasainggrisonlinegratis.blogspot.com/2014/09/manfaat-pentingnya-belajar-bahasa-inggris-di-eraglobalisasi.html

Nordquist, R. (2019). Demonstrative in Grammar. Retrieved from ThoughtCo.: https://www.thoughtco.com/what-is-demonstrative-in-grammar-1690433

Paturusi, M. A. (2016). The students' difficulties in using demonstrative pronoun. Jurnal Pendidikan Bahasa Inggris EXPOSURE, Vol 5, No 2. doi:https://doi.org/10.26618/exposure.v5i2.841

PORTAL-ILMU.COM. (2016). Pentingnya bahasa Inggris di era globalisasi. Retrieved from PORTAL-ILMU.COM: https://www.sitrobbani.sch.id/2020/04/pentingnya-belajarbahasa-inggris-di_11.html

Prahani, B. K. (2019). Cara menulis artikel ilmiah: pendahuluan (introduction). Retrieved from MEDIA ILMU: https://www.ilmiahku.com/2019/03/cara-menulispendahuluanintriduction.html

Prasetyo, A. (2017). Pengertian penelitian deskriptif kualitatif. Retrieved from Linguistik Id: https://www.linguistikid.com/2016/09/pengertian-penelitian-deskriptif-kualitatif.html

Setiawan, P. (2021). Pengertian bahasa menurut para ahli. Retrieved from GuruPendidikan.Com: https://www.gurupendidikan.co.id/pengertian-bahasa-menurutpara-ahli/

Suryani, A. I. (2014). A contrastive study of demonstrative pronoun in english. Jurnal Genta Mulia, 51-71.

Suryani, A. I. (2014). A contrastive study of demonstrative pronoun in english adn japanese. Jurnal Genta Mulia, 51-71.

Winarti, A. (2020). Contrastive analysis between indonesian and english demonstrative pronouns. Jurnal Literasi, Vol 1 No.1. Retrieved from http://jkqh.uniqhba.ac.id/index.php/literasi/article/view/151

Y.Briones, R. R. (2017). A demonstrative analysis of news articles using Fairclough's critical discourse analysis framework. Beyond Words. doi:https://doi.org/10.33508/bw.v5i1.1117 